ARTICLE

\title{
Lamella-nanostructured eutectic zinc-aluminum alloys as reversible and dendrite-free anodes for aqueous rechargeable batteries
}

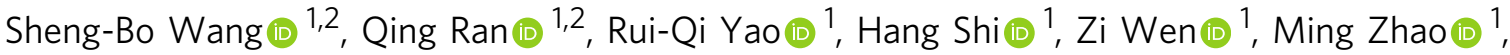 \\ Xing-You Lang (10 ${ }^{1 \times} \&$ Qing Jiang (1) ${ }^{1 凶}$
}

Metallic zinc is an attractive anode material for aqueous rechargeable batteries because of its high theoretical capacity and low cost. However, state-of-the-art zinc anodes suffer from low coulombic efficiency and severe dendrite growth during stripping/plating processes, hampering their practical applications. Here we show that eutectic-composition alloying of zinc and aluminum as an effective strategy substantially tackles these irreversibility issues by making use of their lamellar structure, composed of alternating zinc and aluminum nanolamellas. The lamellar nanostructure not only promotes zinc stripping from precursor eutectic $\mathrm{Zn}_{88} \mathrm{Al}_{12}$ (at\%) alloys, but produces core/shell aluminum/aluminum sesquioxide interlamellar nanopatterns in situ to in turn guide subsequent growth of zinc, enabling dendritefree zinc stripping/plating for more than $2000 \mathrm{~h}$ in oxygen-absent aqueous electrolyte. These outstanding electrochemical properties enlist zinc-ion batteries constructed with $\mathrm{Zn}_{88} \mathrm{Al}_{12}$ alloy anode and $\mathrm{K}_{x} \mathrm{MnO}_{2}$ cathode to deliver high-density energy at high levels of electrical power and retain $100 \%$ capacity after 200 hours.

\footnotetext{
${ }^{1}$ Key Laboratory of Automobile Materials (Jilin University), Ministry of Education, and School of Materials Science and Engineering, Jilin University, Changchun 130022, China. ${ }^{2}$ These authors contributed equally: Sheng-Bo Wang, Qing Ran. ${ }^{凶}$ email: xylang@jlu.edu.cn; jiangq@jlu.edu.cn
} 
W idespread utilization of plentiful but only intermittently available solar and wind power has raised urgent demand for the development of safe, cost-effective, and reliable grid-scale energy storage technologies for efficient integration of renewable energy sources ${ }^{1,2}$. Among many electrochemical energy storage technologies, rechargeable battery based on $\mathrm{Zn}$ metal chemistry in neutral aqueous electrolyte is one of the most attractive devices by virtue of metallic $\mathrm{Zn}$ having high volumetric and gravimetric capacity $\left(5854 \mathrm{mAh} \mathrm{cm}^{-3}\right.$ and 820 $\mathrm{mAh} \mathrm{g}^{-1}$ ), low $\mathrm{Zn} / \mathrm{Zn}^{2+}$ redox potential $(-0.76 \mathrm{~V}$ versus standard hydrogen electrode), high abundance and low $\operatorname{cost}^{3,4}$. Along with high ionic conductivities (up to $1 \mathrm{~S} \mathrm{~cm}^{-1}$ ) of aqueous electrolytes and two-electron redox reaction of $\mathrm{Zn} / \mathrm{Zn}^{2+}$ that favor high rate capability and high energy density, respectively, aqueous rechargeable $\mathrm{Zn}$-ion batteries (AR-ZIBs) promise safe and lowcost high-density energy storage/delivery at fast charge/discharge rates for stationary grid storage applications $s^{5,6}$. This has prompted the recent renaissance of AR-ZIBs ${ }^{4,7,8}$, with the development of various cathode materials including polymorphous manganese dioxides $^{9-13}$, vanadium oxides ${ }^{14-19}$, Prussian blue analogues $(\mathrm{PBAs})^{20,21}$ and quinone analogs ${ }^{22}$ for hosting/delivering $\mathrm{Zn}^{2+}$ and/or $\mathrm{H}^{+}$via insertion/extraction or chemical conversion reactions ${ }^{23-25}$. However, no matter which advanced material is employed as the cathode, state-of-the-art AR-ZIBs are persistently plagued by the irreversibility issues of traditional metallic $\mathrm{Zn}$ anode ${ }^{5,6,8,26}$, such as dendrite formation and growth ${ }^{5,6,8,27,28}$ and low coulombic efficiency (CE) associated with side reactions (e.g., hydrogen evolution, corrosion, and by-product formation) during the stripping/plating processes ${ }^{29-31}$. Although the $\mathrm{Zn}$ dendrite formation could be effectively alleviated in neutral electrolytes compared with in alkaline solutions ${ }^{7-9}$, it is inherently unavoidable because of the unique metallurgic characteristics of monometallic $\mathrm{Zn}^{27,31}$. Furthermore, there always take place uncontrollable shape changes to produce abundant cracks or defects in the repeated processes of $\mathrm{Zn}$ stripping/plating ${ }^{32,33}$. The structural irreversibility triggers further $\mathrm{Zn}$ dendrite growth due to uneven distribution and slow diffusion of $\mathrm{Zn}^{2+}$ ions at the $\mathrm{Zn}$ metal/electrolyte interface ${ }^{33}$ and continuously depletes $\mathrm{Zn}$ and electrolyte via supplementary side reactions ${ }^{30,31}$, leading to rapid and remarkable capacity fading and short lifespan of AR-ZIBs. Therefore, it is highly desirable to explore novel $\mathrm{Zn}$-based anode materials that can circumvent these irreversibility issues for constructing high-performance AR-ZIBs.

Here we report that a class of eutectic $\mathrm{Zn} / \mathrm{Al}$ alloys with an alternating $\mathrm{Zn}$ and $\mathrm{Al}$ lamellar nanostructure as reversible and dendrite-free anode materials significantly improve electrochemical performance of aqueous rechargeable zinc-manganese oxide batteries ( $\mathrm{Zn}-\mathrm{Mn}$ AR-ZIBs). The unique lamellar structure promotes the reversibility of stripping/plating of $\mathrm{Zn}$ by making use of symbiotic less-noble $\mathrm{Al}$ lamellas, which in-situ form interlamellar nanopatterns with an $\mathrm{Al} / \mathrm{Al}_{2} \mathrm{O}_{3}$ core/shell structure. Therein, the $\mathrm{Al}$ protects against irreversible by-product of $\mathrm{ZnO}$ or $\mathrm{Zn}(\mathrm{OH})_{2}$ while the insulating $\mathrm{Al}_{2} \mathrm{O}_{3}$ shell prevents the electroreduction of $\mathrm{Zn}^{2+}$ ions on the $\mathrm{Al} / \mathrm{Al}_{2} \mathrm{O}_{3}$ patterns and thus guides their electrodeposition on the precursor $\mathrm{Zn}$ sites, substantially eliminating the formation and growth of $\mathrm{Zn}$ dendrites. As a result, the eutectic $\mathrm{Zn}_{88} \mathrm{Al}_{12}$ (at\%) alloys exhibit superior dendrite-free $\mathrm{Zn}$ stripping/plating behaviors, with remarkably low and stable overpotential, for more than $2000 \mathrm{~h}$ in $\mathrm{O}_{2}$-absent aqueous $\mathrm{ZnSO}_{4}$ electrolyte. The outstanding electrochemical properties enable the $\mathrm{Zn}-\mathrm{Mn}$ AR-ZIBs constructed with eutectic $\mathrm{Zn}_{88} \mathrm{Al}_{12}$ alloy anode and $\mathrm{K}_{x} \mathrm{MnO}_{2}$ cathode to deliver energy density of $\sim 230 \mathrm{Wh} \mathrm{kg}^{-1}$ (based on the mass of $\mathrm{K}_{x} \mathrm{MnO}_{2}$ cathode) at high levels of electrical power while retaining $\sim 100 \%$ capacity after more than 200 hours. By adjusting the anode-tocathode mass ratio to 3:1, the overall energy density of $\mathrm{Zn}-\mathrm{Mn}$
AR-ZIB can reach $\sim 142 \mathrm{Wh} \mathrm{kg}^{-1}$ based on total mass of anode and cathode. The strategy of eutectic-composition alloying could open an avenue to the development of high-performance metallic anodes for next-generation secondary batteries.

\section{Results}

Eutectic alloying strategy for $\mathrm{Zn}$ dendrite suppression. $\mathrm{Zn}$ metal is a classic anode material but works as a hostless electrode to store/deliver energy via the electrochemical plating/stripping of $\mathrm{Zn}$, during which the $\mathrm{Zn}^{2+}$ cations thermodynamically prefer to form nuclei at the dislocated sites and grow into initial protuberances on the surface of $\mathrm{Zn}$ substrate with uncontrollable $\mathrm{Zn}$ redistribution (Fig. 1a) ${ }^{27-29,31,33}$. In particular, the tips of protuberances not only have higher potentials ${ }^{34}$ but consist of highdensity low-coordination steps and kinks with lower activation energy, both of which facilitate further growth of dendrites (Fig. 1b ${ }^{29}$. To circumvent these irreversibility problems, here we propose an eutectic-composition alloying strategy based on $\mathrm{Zn} / \mathrm{Al}$ alloy system, wherein the eutectic structure is composed of alternating $\mathrm{Zn}$ and $\mathrm{Al}$ lamellas. Although the standard equilibrium potential of $\mathrm{Al}^{3+} / \mathrm{Al}(-1.66 \mathrm{~V}$ versus SHE) is much lower than that of $\mathrm{Zn}^{2+} / \mathrm{Zn}^{35}$, the formation of $\mathrm{Al}_{2} \mathrm{O}_{3}$ shell on the $\mathrm{Al}$ lamellas protects against the dissolution of $\mathrm{Al}$ and thus allows the selectively electrochemical stripping/plating of $\mathrm{Zn}$ in aqueous electrolyte ${ }^{35,36}$. Their distinct electrochemical behaviors enable the different roles of $\mathrm{Zn}$ and $\mathrm{Al}$ lamellas in the charge/discharge processes: the former supplying $\mathrm{Zn}^{2+}$ charge carriers and the latter serving as $2 \mathrm{D}$ hosting skeleton to accommodate the $\mathrm{Zn}$ plating (Fig. 1c). Owing to the insulating $\mathrm{Al}_{2} \mathrm{O}_{3}$ shell that substantially blocks the electron transfer from $\mathrm{Al}$ to the $\mathrm{Zn}^{2+}$ cations $^{35}$, there forms a positive electrostatic shield around the $\mathrm{Al} / \mathrm{Al}_{2} \mathrm{O}_{3}$ lamellas without the reduction of $\mathrm{Zn}^{2+37}$, enlisting the $\mathrm{Al} / \mathrm{Al}_{2} \mathrm{O}_{3}$ nanopatterns to guide the uniform $\mathrm{Zn}$ deposition at their interlayer spacing along the Zn precursor sites (Fig. 1d).

Preparation and characterization of eutectic $\mathrm{Zn}$-Al alloys. Eutectic $\mathrm{Zn}_{88} \mathrm{Al}_{12}$ (at\%) alloys are produced by a facile and scalable metallurgic procedure, viz. alloying pure $\mathrm{Zn}$ and $\mathrm{Al}$ metals and pouring casting at various cooling rates from $\sim 10$ to $\sim 300 \mathrm{~K} \mathrm{~s}^{-1}$. Supplementary Fig. 1 shows typical X-ray diffraction (XRD) patterns of eutectic $\mathrm{Zn}_{88} \mathrm{Al}_{12}$ alloys, with the major peaks corresponding to the primary hexagonal closest packed (hcp) $\mathrm{Zn}$ phase (JCPDS 04-0831), apart from the weak ones attributed to the face-centered cubic (fcc) $\alpha$-Al phase (JCPDS 04-0787) (Fig. 2a). Distinguished from hypoeutectic $Z_{50} \mathrm{Al}_{50}$ alloy that is composed of random eutectic mixtures of $\mathrm{Zn}$ and $\mathrm{Al}$ (Supplementary Figs. 2 and 3$)^{38}$, the eutectic $\mathrm{Zn}_{88} \mathrm{Al}_{12}$ alloys exhibit an ordered lamellar structure of alternating $\mathrm{Zn}$ and $\mathrm{Al}$ lamellas. As a result of the rapid solidification triggered $\mathrm{Al}$ phase precipitation as well as the balance between the lateral diffusion of excess $\mathrm{Zn}$ and $\mathrm{Al}$ in the liquid just ahead of the solid/liquid interface and the creation of $\mathrm{Zn} / \mathrm{Al}$ interfacial area during the solidification process $^{39,40}$, the thickness of $\mathrm{Zn}$ or $\mathrm{Al}$ lamellas, or the interlamellar spacing $(\lambda)$, decreases with the cooling rates (Fig. 2b). Figure $2 c-e$ show representative optical micrographs of the lamella-structured eutectic $\mathrm{Zn}_{88} \mathrm{Al}_{12}$ alloys, which are prepared at the cooling rates of $\sim 10, \sim 30$ and $\sim 300 \mathrm{~K} \mathrm{~s}^{-1}$, respectively. At the slow cooling rate of $\sim 10 \mathrm{~K} \mathrm{~s}^{-1}$, the $\lambda$ of the eutectic $\mathrm{Zn}_{88} \mathrm{Al}_{12}$ alloy is $\sim 450 \mathrm{~nm}$ (Fig. $2 \mathrm{c}$ and Supplementary Fig. 4 a), i.e., $\sim 350 \mathrm{~nm}$ thick Zn lamellas (sagging stripes) alternatingly sandwiched by the $\mathrm{Al}$ ones (protruding stripes) with thickness of $\sim 100 \mathrm{~nm}$ (Supplementary Fig. 5). The unique lamellar structure is further illustrated by scanning electron microscope (SEM) backscattered electron image and the corresponding energy-dispersive X-ray spectroscopy (EDS) elemental mappings, with the uniform 


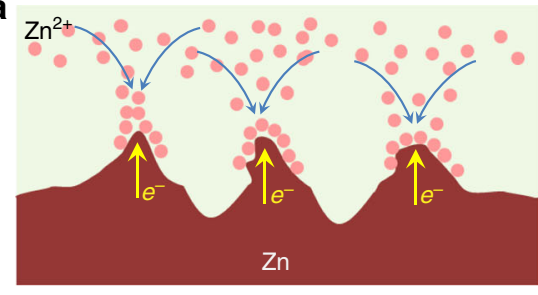

Uncontrollable volume change and tip effect

C

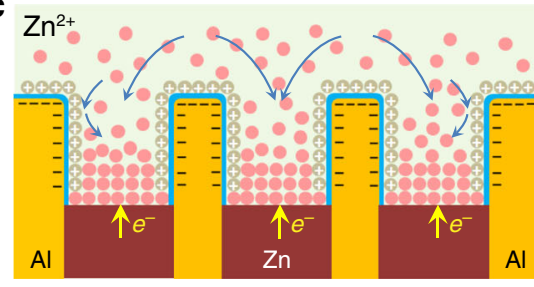

Electrostatic shield and guiding growth

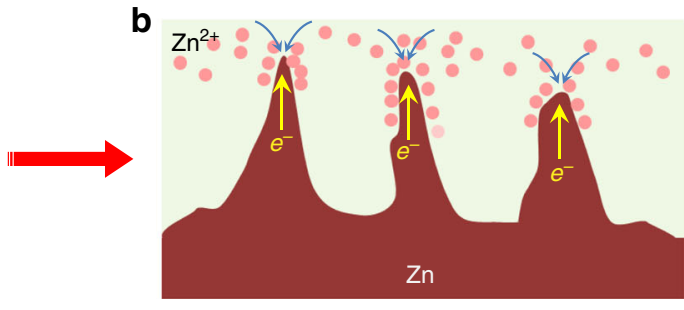

Formation of dendrites
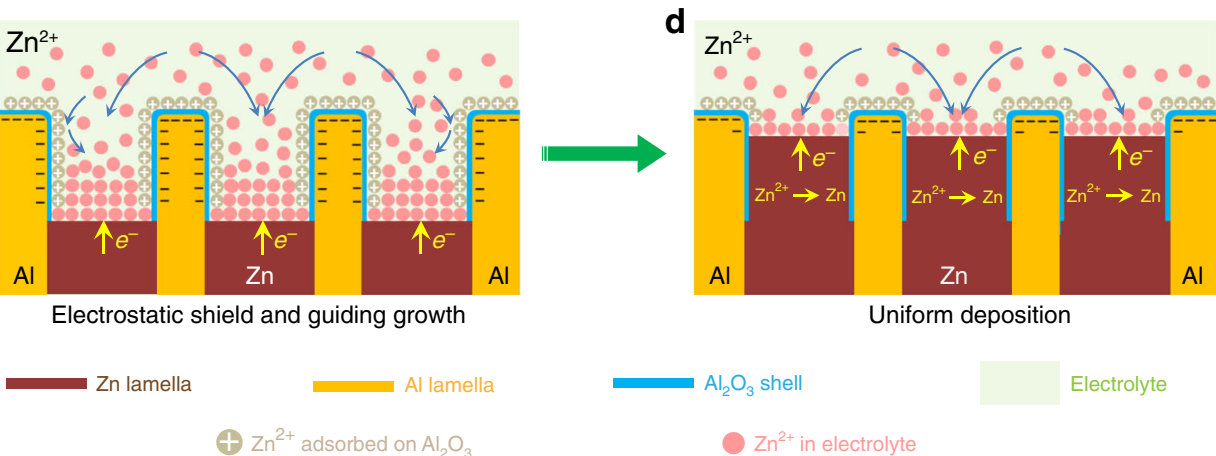

$\mathrm{Zn}^{2+}$ in electrolyte

Fig. 1 Schematic illustration of eutectic strategy for dendrite and crack suppression. a Monometallic Zn electrodes with abundant cracks or defects that are produced by uncontrollable volume change in the Zn stripping/plating processes. b Growth of Zn dendrites triggered by uncontrollable volume change and tip effect. c Eutectic $\mathrm{Zn} / \mathrm{Al}$ alloys with a lamellar structure composed of alternative $\mathrm{Zn}$ and $\mathrm{Al}$ nanolamellas in-situ produce core/shell interlayer patterns during the $\mathrm{Zn}$ stripping to guide the subsequent $\mathrm{Zn}$ plating. $\mathbf{d}$ The $\mathrm{Al} / \mathrm{Al}_{2} \mathrm{O}_{3}$ interlayer patterns associated with insulative $\mathrm{Al}_{2} \mathrm{O}_{3}$ shield facilitate the uniform deposition of Zn.

distribution of alternating $\mathrm{Zn}$ and $\mathrm{Al}$ lamellas (Fig. 2f). While increasing the cooling rate to $\sim 300 \mathrm{~K} \mathrm{~s}^{-1}$, the $\lambda$ reaches $\sim 1850 \mathrm{~nm}$, with $\sim 1200$-nm-thick Zn lamellas and $\sim 650-\mathrm{nm}$ thick Al lamellas (Fig. 2e and Supplementary Fig. 4c). Figure $2 \mathrm{~g}$ shows a typical high-resolution transmission electron microscope (HRTEM) image of $\mathrm{Zn} / \mathrm{Al}$ interfacial region, demonstrating the symbiotic $\mathrm{Zn}$ and $\mathrm{Al}$ lamellas viewed along their $\langle 0001\rangle$ and $\langle 111\rangle$ zone axis. The fast Fourier transform (FFT) patterns of the selected areas in Fig. $2 \mathrm{~g}$ confirm the fcc $\mathrm{Al}$ phase (Fig. 2h) and the hcp Zn phase (Fig. 2i) separated from each other during the solidification process 39,40 .

Despite the immiscibility of $\mathrm{Zn}$ and $\mathrm{Al}$ metals, the lamellastructured eutectic $\mathrm{Zn}_{88} \mathrm{Al}_{12}$ exhibits remarkable alloy nature, with a superior oxidation-resistance capability in air and aqueous electrolytes compared with monometallic $\mathrm{Zn}$, because of the formation of stable and passive $\mathrm{Al}_{2} \mathrm{O}_{3}$ surface layer, which protects against the further oxidation ${ }^{39,40}$. As shown in optical photographs (Supplementary Fig. 6a), the eutectic $\mathrm{Zn}_{88} \mathrm{Al}_{12}$ alloy still displays a metallic lustre after exposed to air for five days, in sharp contrast with monometallic $\mathrm{Zn}$ that undergoes severe oxidation. Furthermore, the thinner the interlamellar spacing, the higher the oxidation-resistance capability. Even when immersing in the $\mathrm{O}_{2}$-present $\mathrm{ZnSO}_{4}$ aqueous electrolyte for $72 \mathrm{~h}$, the eutectic $\mathrm{Zn}_{88} \mathrm{Al}_{12}$ alloy with $\lambda=\sim 450 \mathrm{~nm}$ does not display evident change (Supplementary Fig. 6b). The superior oxidation-resistance behavior of eutectic $\mathrm{Zn}_{88} \mathrm{Al}_{12}$ alloys is further demonstrated by their EIS measurements, which are performed on the basis of a classic three-electrode configuration with $\mathrm{Pt}$ foil as the counter electrode and an $\mathrm{Ag} / \mathrm{AgCl}$ electrode as the reference electrode, in the $\mathrm{O}_{2}$-present $\mathrm{ZnSO}_{4}$ electrolyte (Fig. 3a and Supplementary Fig. $7 \mathrm{~b}$ ). In the Nyquist plot, the EIS spectra of eutectic $\mathrm{Zn}_{88} \mathrm{Al}_{12}$ alloys, hypoeutectic $\mathrm{Zn}_{50} \mathrm{Al}_{50}$ alloy and monometallic $\mathrm{Zn}$ display characteristic semicircles with distinct diameters in the high- and middle-frequency range. At high frequencies, the intercept at the real part represents the intrinsic resistance of both electrolyte and electrode $\left(R_{\mathrm{I}}\right)$; in the middle-frequency range, the diameter of semicircle corresponds to the charge transfer resistance $\left(R_{\mathrm{CT}}\right)$ and the double-layer capacitance $\left(C_{\mathrm{F}}\right)$; and the slope of the inclined line at flow frequencies is the Warburg resistance $(Z w)$. Based on the equivalent circuit with these general descriptors (Supplementary Fig. 7a), the EIS spectra are analyzed using the complex nonlinear least-squares fitting method. Supplementary Fig. 7c compares the $R_{\mathrm{I}}$ values of all $\mathrm{Zn}$-based electrodes immersed in the $\mathrm{O}_{2}$-present electrolyte for $1 \mathrm{~h}$, wherein the $\mathrm{Zn}_{88} \mathrm{Al}_{12}$ with $\lambda=$ $\sim 450 \mathrm{~nm}$ has the lowest $R_{\mathrm{I}}$ value $(\sim 11 \Omega)$ because of the outstanding oxidation-resistance property. Even extending the immersion time to $10 \mathrm{~h}$, the $\mathrm{Zn}_{88} \mathrm{Al}_{12}$ still maintains $\sim 11 \Omega$ whereas the $\mathrm{Zn}$ electrode has the $R_{\mathrm{I}}$ value to increase to $\sim 22 \Omega$ from $\sim 18 \Omega$. The large change of $R_{\mathrm{I}}$ value indicates the inferior oxidation-resistance capability of the monometallic $\mathrm{Zn}$. Owing to their different oxidation-resistance capabilities, there form distinct oxide layers to depress the $\mathrm{Zn}$ stripping/plating kinetics, indicated by the increase of $R_{\mathrm{CT}}$ value. When immersed in the $\mathrm{O}_{2}$-present electrolyte for 1 and $10 \mathrm{~h}$, the $\mathrm{Zn}_{88} \mathrm{Al}_{12}$ with $\lambda=\sim 450$ $\mathrm{nm}$ exhibits exceptional stability with the $R_{\mathrm{CT}}$ value changing from $\sim 32 \Omega$ to $\sim 36 \Omega$, in sharp contrast with the monometallic $\mathrm{Zn}$ electrode with a remarkable change of $R_{\mathrm{CT}}$ from $\sim 96 \Omega$ to $\sim 177 \Omega$ (Fig. 3b). This is probably because there lacks a passivation film on the $\mathrm{Zn}$ lamella surface in virtue of the protection of neighboring $\mathrm{Al}$ lamellas ${ }^{5,26}$. More impressively, the superior oxidation-resistance capability enlists the eutectic $\mathrm{Zn}_{88} \mathrm{Al}_{12}$ alloys to be more conducive to electron transfer during the electrochemical $\mathrm{Zn}$ stripping/plating processes in the $\mathrm{O}_{2-}$ absent $\mathrm{ZnSO}_{4}$ aqueous electrolyte. As demonstrated by EIS spectra in Fig. $3 c$, the eutectic $\mathrm{Zn}_{88} \mathrm{Al}_{12}$ with $\lambda=\sim 450 \mathrm{~nm}$ has the $R_{\mathrm{I}}$ and $R_{\mathrm{CT}}$ values of as low as $\sim 9 \Omega$ and $\sim 24 \Omega$, respectively (Fig. 3d and Supplementary Fig. 7e). Although the increase of $\lambda$ may weaken the protecting effect of $\mathrm{Al}$ on the eutectic $\mathrm{Zn}_{88} \mathrm{Al}_{12}$, the value of $R_{\mathrm{CT}}$ is only about half of that of the monometallic $\mathrm{Zn}$ $(\sim 82 \Omega)$ (Fig. 3d and Supplementary Fig. 8). 

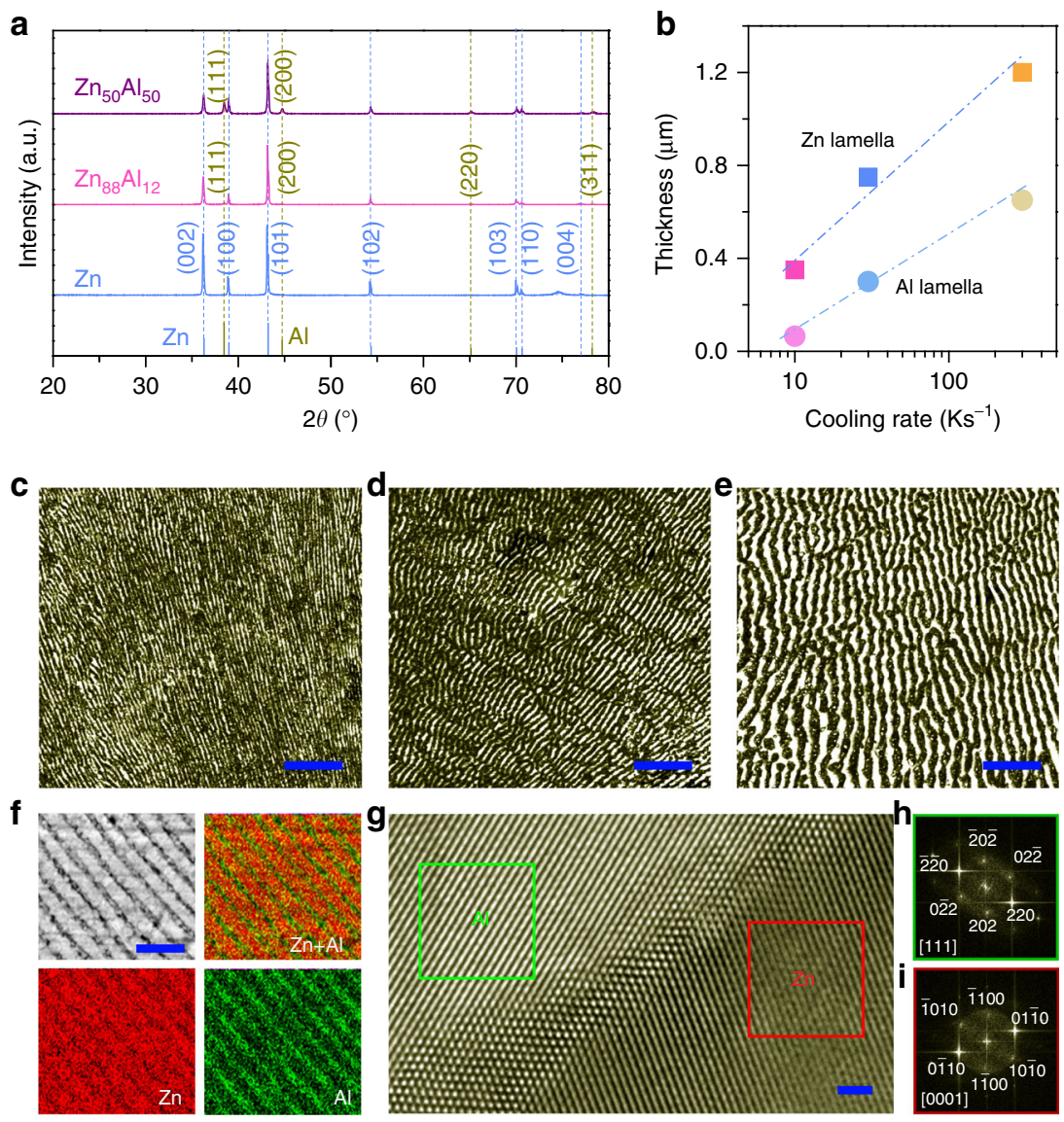

Fig. 2 Microstructure characterization of eutectic $\mathbf{Z n} / \mathbf{A l}$ alloys. a XRD patterns of monometallic $Z n$, hypoeutectic $Z_{n_{50}} A l_{50}$ and eutectic $Z n_{88} A l_{12}$ alloys. The line patterns show reference cards 04-0831 for hcp $\mathrm{Zn}$ (blue) and 04-0787 for fcc Al (dark yellow) according to JCPDS. b Thickness of $\mathrm{Zn}$ and Al layers in lamella-nanostructured eutectic $\mathrm{Zn}_{88} \mathrm{Al}_{12}$ alloys that are produced at various cooling rates. c-e Optical micrographs of lamella-nanostructured eutectic $\mathrm{Zn}_{88} \mathrm{Al}_{12}$ alloys with lamella spacing of $\sim 450 \mathrm{~nm}(\mathbf{c}), \sim 1050 \mathrm{~nm}$ (d) and $\sim 1850 \mathrm{~nm}$ (e). Scale bar, $10 \mu \mathrm{m}$ (c-e), Typical SEM image lamellananostructured eutectic $\mathrm{Zn}_{88} \mathrm{Al}_{12}$ alloys with lamella spacing of $\sim 450 \mathrm{~nm}$ and the corresponding EDS element mapping of $\mathrm{Zn}$ and Al. Scale bar, $2 \mu \mathrm{m}$. $\mathbf{g}$, HRTEM image of $\mathrm{Zn} / \mathrm{Al}$ interface of eutectic $\mathrm{Zn}_{88} \mathrm{Al}{ }_{12}$ alloys $(\lambda=\sim 450 \mathrm{~nm})$. Scale bar, $1 \mathrm{~nm}$. $\mathbf{h}, \mathbf{i}$, FFT patterns of selected areas of HRTEM image $(\mathbf{g})$ that correspond to fcc $\mathrm{Al}(\mathbf{h})$ and hcp $\mathrm{Zn}(\mathbf{i})$, respectively.

Electrochemical properties of eutectic $\mathrm{Zn}_{88} \mathrm{Al}_{12}$ alloys. To investigate the $\mathrm{Zn}$ stripping/plating behaviors of the Zn-based electrodes, electrochemical measurements are performed on symmetric batteries that are constructed with two identical electrodes. Figure 4a shows the voltage profiles of the eutectic $\mathrm{Zn}_{88} \mathrm{Al}_{12}$ symmetric battery during the $\mathrm{Zn}$ plating/stripping processes at various current densities in the $\mathrm{O}_{2}$-absent $\mathrm{ZnSO}_{4}$ electrolyte, comparing with those of the hypoeutectic $\mathrm{Zn}_{50} \mathrm{Al}_{50}$ and monometallic $\mathrm{Zn}$ ones. The battery based on the eutectic $\mathrm{Zn}_{88} \mathrm{Al}_{12}$ alloy with $\lambda=\sim 450 \mathrm{~nm}$ exhibits a relatively flat and stable voltage plateau with the absolute overpotential of $\sim 20 \mathrm{mV}$ at the rate of $1 \mathrm{C}$ (where $1 \mathrm{C}$ represents a one-hour complete charge or discharge at the current density of $\left.0.5 \mathrm{~mA} \mathrm{~cm}^{-2}\right)$, much lower than the value of symmetric $\mathrm{Zn}$ battery $(\sim 101 \mathrm{mV})$. The less polarization is probably due to the unique eutectic structure of alternating $\mathrm{Zn}$ and $\mathrm{Al}$ lamellas in the $\mathrm{Zn}_{88} \mathrm{Al}_{12}$ alloy. Therein, the constituent Al lamellas not only protect against the passivation of the electroactive $\mathrm{Zn}$ but reduce the local current density of $\mathrm{Zn}$ stripping/plating via the formation of core/shell $\mathrm{Al} / \mathrm{Al}_{2} \mathrm{O}_{3}$ lamellar nanopatterns (Supplementary Fig. 9a) ${ }^{41,42}$, which guide the uniform $\mathrm{Zn}$ electrodeposition in the subsequent plating process (Supplementary Fig. 9b). During the Zn stripping/plating, the XRD and Raman spectroscopy characterizations evidence the absence of passivation film on the electroactive $\mathrm{Zn}$ lamellas of $\mathrm{Zn}_{88} \mathrm{Al}_{12}$ (Supplementary Fig. 10a, c), which usually forms on the monometallic Zn electrode. As shown in Supplementary Fig. 10b, $\mathrm{d}$ for the $\mathrm{Zn}$ electrode after cycling test, there appear neoformative diffraction peaks and characteristic Raman bands corresponding to $\mathrm{Zn}_{4} \mathrm{SO}_{4}(\mathrm{OH})_{6} \cdot \mathrm{H}_{2} \mathrm{O}$ in addition to $\mathrm{ZnO}^{4,8,11,43}$. These observations are in agreement with surface chemical states of $\mathrm{Zn}$ or/and $\mathrm{Al}$, which are analyzed by X-ray photoelectron spectroscopy (XPS). After cycling test, the surface $\mathrm{Zn}$ of monometallic $\mathrm{Zn}$ electrode is completely oxidized because of the formation of $\mathrm{Zn}_{4} \mathrm{SO}_{4}(\mathrm{OH})_{6} \cdot \mathrm{H}_{2} \mathrm{O}$ and $\mathrm{ZnO}$ (Supplementary Fig. 11a), different from that of the pristine one with primary metallic $\mathrm{Zn}^{0}$ in addition to some $\mathrm{Zn}^{2+}$ due to the initial surface oxidation (Supplementary Fig. 11b). While for the $\mathrm{Zn}_{88} \mathrm{Al}_{12}$ electrode after cycling test, the Zn $2 \mathrm{p}$ and Al $2 \mathrm{p}$ XPS spectra reveal that the surface $\mathrm{Zn}$ maintains almost the same chemical states as that in the pristine one (Supplementary Fig. 11c, e), but the metallic $\mathrm{Al}$ mainly becomes $\mathrm{Al}^{3+}$ as a consequence of the formation of $\mathrm{Al}_{2} \mathrm{O}_{3}$ shell (Supplementary Fig. 11d, f). As the stripping/plating rate increases to $5 \mathrm{C}$, the overpotential of the symmetric $\mathrm{Zn}_{88} \mathrm{Al}_{12}$ battery only increases to $\sim 82 \mathrm{mV}$, implying the excellent rate capability of eutectic $\mathrm{Zn}_{88} \mathrm{Al}_{12}$ alloy electrode. The high reversibility of $\mathrm{Zn}$ stripping/plating on the eutectic $\mathrm{Zn}_{88} \mathrm{Al}_{12}$ alloy electrode is further attested by chronocoulometry measurements based on a three-electrode cell, in which the $\mathrm{Zn}$ electrodes are employed as the reference and counter electrodes (inset of Supplementary Fig. 12). The $\mathrm{Zn}$ stripping/plating on the eutectic 

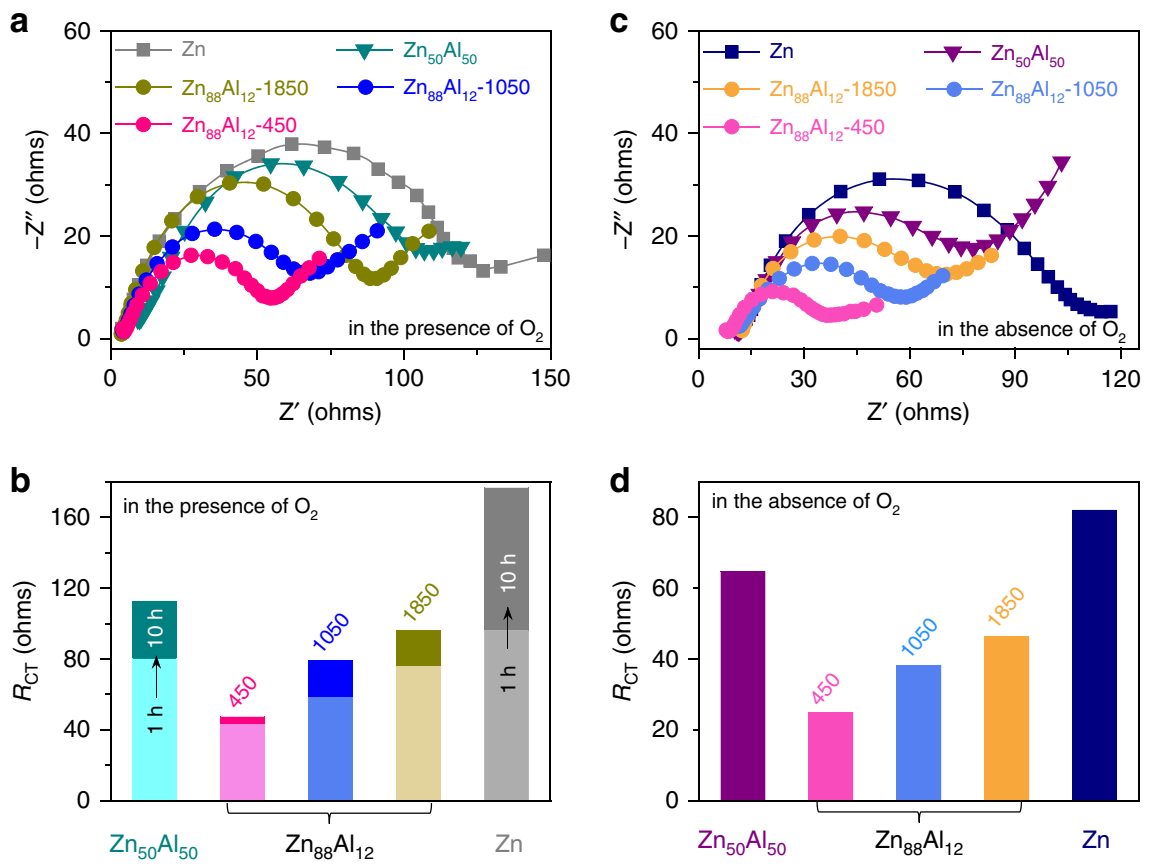

Fig. 3 Oxidation-resistance capability of $\mathbf{Z n}$ metal and eutectic $\mathbf{Z n} / \mathbf{A l}$ alloys. a Electrochemical impedance spectra (EIS) of eutectic $Z \mathrm{n}_{88} \mathrm{Al}_{12}$ alloys with various lamellar spacings $\left(\lambda=\sim 450, \sim 1050\right.$ and $\sim 1850 \mathrm{~nm}$ ), hypoeutectic $\mathrm{Zn}_{50} \mathrm{Al}_{50}$ alloy and monometallic $\mathrm{Zn}$ after immersed in the $\mathrm{O}_{2}$-present $\mathrm{ZnSO}{ }_{4}$ aqueous electrolytes for $1 \mathrm{~h}$. $\mathbf{b}$ Evolutions of the charge transfer resistances $\left(R_{\mathrm{CT}}\right)$ of eutectic $\mathrm{Zn}_{88} \mathrm{Al}_{12}$ alloys with various lamellar spacings $(\lambda=\sim 450$, $\sim 1050$ and $\sim 1850 \mathrm{~nm}$ ), hypoeutectic $\mathrm{Zn}_{50} \mathrm{Al}_{50}$ alloy and monometallic $\mathrm{Zn}$ when extending the immersing time from 1 to $10 \mathrm{~h}$ in the $\mathrm{O}_{2}-\mathrm{present}_{\mathrm{ZnSO}}$ aqueous electrolytes. $\mathbf{c}$, $\mathbf{d}$ EIS spectra of eutectic $\mathrm{Zn}_{88} \mathrm{Al}_{12}$ alloys with various lamellar spacings $(\lambda=\sim 450, \sim 1050$ and $\sim 1850 \mathrm{~nm})$, hypoeutectic $Z \mathrm{n}_{50} \mathrm{Al} \mathrm{l}_{50}$ alloy and monometallic $\mathrm{Zn}(\mathbf{c})$ and their corresponding $R_{C T}$ values (d) in the $\mathrm{O}_{2}$-absent $\mathrm{ZnSO}_{4}$ aqueous electrolyte for $1 \mathrm{~h}$.

$\mathrm{Zn}_{88} \mathrm{Al}_{12}$ alloy is highly reversible, with the CE of $\sim 100 \%$, during the cycling test for more than 100 cycles (Supplementary Fig. 12).

During a long-term $\mathrm{Zn}$ stripping/plating cycling measurement, the voltage profile of $\mathrm{Zn}_{88} \mathrm{Al}_{12}$ battery does not display any evident voltage hysteresis or change even for more than $2000 \mathrm{~h}$, in sharp contrast to those of the $\mathrm{Zn}_{50} \mathrm{Al}_{50}$ and $\mathrm{Zn}$ ones with much larger voltage hysteresis and fluctuation after 100 and 26 hours, respectively (Fig. 4b). Specifically, there takes place an abrupt voltage drop after a dramatic voltage increase in the $\mathrm{Zn}$ battery, which is caused by a short circuit of battery due to the formation of $\mathrm{Zn}$ dendrites. EIS spectra also justify the outstanding stability of the $\mathrm{Zn}_{88} \mathrm{Al}_{12}$ alloy electrode during the $\mathrm{Zn}$ stripping/plating processes because of the unique eutectic structure (Fig. $4 \mathrm{c}-\mathrm{e}$ ). Furthermore, the fact that inductively coupled plasma optical emission spectroscopy (ICP-OES) cannot detect $\mathrm{Al}^{3+}$ ions in the $\mathrm{O}_{2}$-absent aqueous electrolytes demonstrates the chemical stability of $\mathrm{Al} / \mathrm{Al}_{2} \mathrm{O}_{3}$ interlamellar nanopatterns (Supplementary Table 1), which in turn guide the deposition of $\mathrm{Zn}$ after a longterm cycling test of the $\mathrm{Zn}_{88} \mathrm{Al}_{12}$. As shown in Fig. 4f, the eutectic $\mathrm{Zn}_{88} \mathrm{Al}_{12}$ alloy electrode still keeps a smooth surface after more than 1000 cycles of $\mathrm{Zn}$ stripping/plating. This is distinctly distinguished from the cycled hypoeutectic $\mathrm{Zn}_{50} \mathrm{Al}_{50}$ and monometallic $\mathrm{Zn}$ electrodes even in fewer cycles, wherein the former displays an uneven porous structure (Fig. $4 \mathrm{~g}$ ) and the latter undergoes severe growth of dendrites and cracks (Fig. 4h). The addition of $\mathrm{Mn}^{2+}$ ions in the aqueous $\mathrm{ZnSO}_{4}$ electrolyte does not remarkably influence the $\mathrm{Zn}$ stripping/plating behavior of $\mathrm{Zn}_{88} \mathrm{Al}_{12}$ alloy. As shown in Supplementary Fig. 13, the $\mathrm{Zn}_{88} \mathrm{Al}_{12}$ battery exhibits almost the same voltage-time profiles in the $2 \mathrm{M}$ $\mathrm{ZnSO}_{4}$ electrolyte without/with $0.2 \mathrm{M} \mathrm{MnSO}_{4}$. While in the $\mathrm{ZnSO}_{4}$ electrolyte with the $\mathrm{O}_{2}$ concentration of $16.59 \mathrm{mg} \mathrm{L}^{-1}$, the eutectic $\mathrm{Zn}_{88} \mathrm{Al}_{12}$ battery exhibits a stable voltage profile for more than 400 hours (Supplementary Fig. 14a), followed by slightly increasing voltage hysteresis due to the morphology evolution probably triggered by the partial oxidation of $\mathrm{Zn}$ via the reactions (Supplementary Fig. 14b) ${ }^{8,43}: \mathrm{Zn}_{88} \mathrm{Al}_{12}+\mathrm{O}_{2}+\mathrm{H}_{2} \mathrm{O} \rightarrow \mathrm{Al}_{2} \mathrm{O}_{3}+$ $\mathrm{Zn}(\mathrm{OH})_{2}+\mathrm{Zn}^{2+}+\mathrm{e}^{-}$and $\mathrm{Zn}(\mathrm{OH})_{2}+2 \mathrm{e}^{-} \rightarrow \mathrm{ZnO}+\mathrm{H}_{2} \mathrm{O}^{11}$. Nevertheless, the lamellar structure of alternating $\mathrm{Zn}$ and $\mathrm{Al}$ lamellas significantly alleviate structure changes, in comparison with the electrodes of hypoeutectic $\mathrm{Zn}_{50} \mathrm{Al}_{50}$ alloy and monometallic Zn (Supplementary Fig. 14c-e).

Electrochemical performance of $\mathbf{Z n}$-ion full batteries. In view of the outstanding electrochemical properties, the lamella-structured eutectic $\mathrm{Zn}_{88} \mathrm{Al}_{12}$ alloy with $\lambda=\sim 450 \mathrm{~nm}$ is used as the anode to couple with potassium manganese oxide $\left(\mathrm{K}_{x} \mathrm{MnO}_{2}\right)$ cathode material for demonstrating its actual application in $\mathrm{Zn}$-ion full batteries, with an aqueous electrolyte containing $2 \mathrm{M} \mathrm{ZnSO}_{4}$ and $0.2 \mathrm{M} \mathrm{MnSO}_{4}$. Therein, tetragonal $\alpha-\mathrm{K}_{x} \mathrm{MnO}_{2}$ nanofibers are synthesized by a stirring hydrothermal approach (Supplementary Fig. 15) ${ }^{44}$. Supplementary Fig. 16a shows typical cyclic voltammetry (CV) curves of $\mathrm{Zn}_{88} \mathrm{Al}_{12} / \mathrm{K}_{x} \mathrm{MnO}_{2}$ full battery in the aqueous electrolytes, without and with the presence of $\mathrm{O}_{2}$, exhibiting a similar $\mathrm{Zn}$ storage/delivery behavior with well-defined redox peaks during the charge/discharge processes $4,7,8,10-12$. It implies that the electrolyte in the absence of $\mathrm{O}_{2}$ does not substantially change the $\mathrm{Zn}^{2+}$ (de-)intercalation mechanism within the $\mathrm{K}_{x} \mathrm{MnO}_{2}$, i.e., $\delta \mathrm{Zn}^{2+}+2 \delta \mathrm{e}^{-}+\mathrm{K}_{x} \mathrm{MnO}_{2} \leftrightarrow$ $\delta \mathrm{ZnK}_{x} \mathrm{MnO}_{2} 4,7,8,10-12$, except for boosting the reaction kinetics of $\mathrm{Zn}$ stripping/plating due to the absence of passivation oxide (e.g., $\mathrm{ZnO}$ or $\mathrm{Zn}(\mathrm{OH})_{2}$ ) on the $\mathrm{Zn}$ lamella surface of the $\mathrm{Zn}_{88} \mathrm{Al}_{12}$ (Supplementary Fig. 16b).

Figure 5a compares representative $\mathrm{CV}$ curve of $\mathrm{Zn}$-ion batteries that are constructed with the $\mathrm{K}_{x} \mathrm{MnO}_{2}$ cathode and the $\mathrm{Zn}_{88} \mathrm{Al}_{12}$ or $\mathrm{Zn}$ anode, in the $\mathrm{O}_{2}$-absent aqueous electrolyte. The use of different anode materials, i.e., the lamella-structured eutectic $\mathrm{Zn}_{88} \mathrm{Al}_{12}$ alloy and the single-phase structured monometallic $\mathrm{Zn}$, enlists them to exhibit distinct voltammetric behaviors. Relative 
a

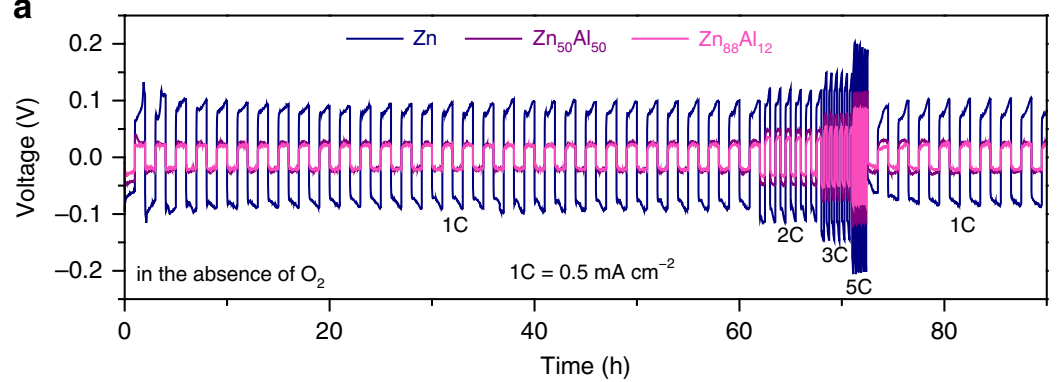

b

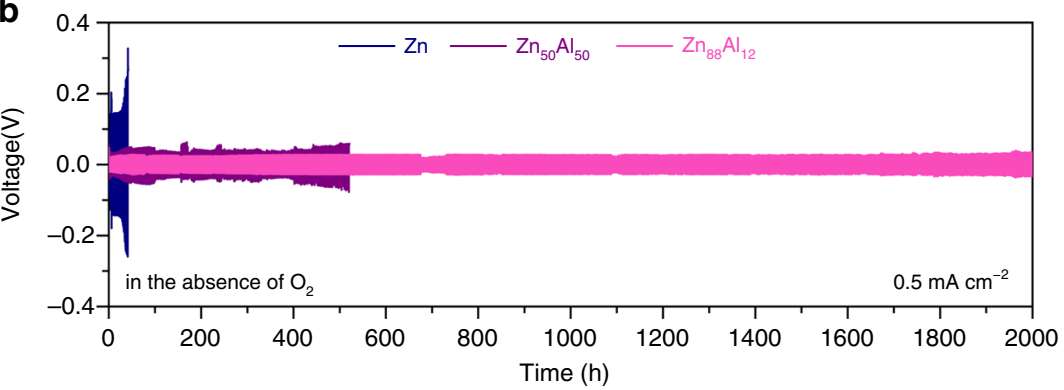

$\mathbf{f}$

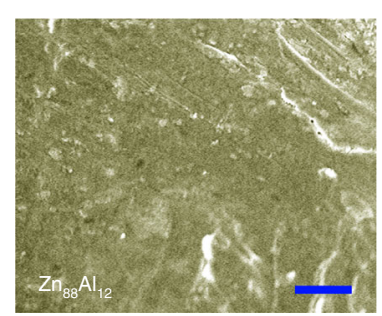

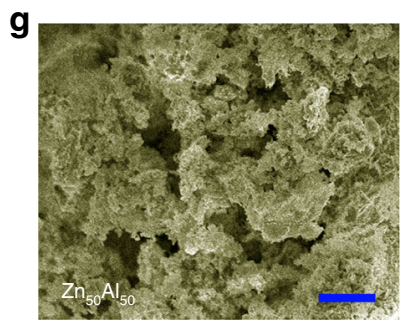
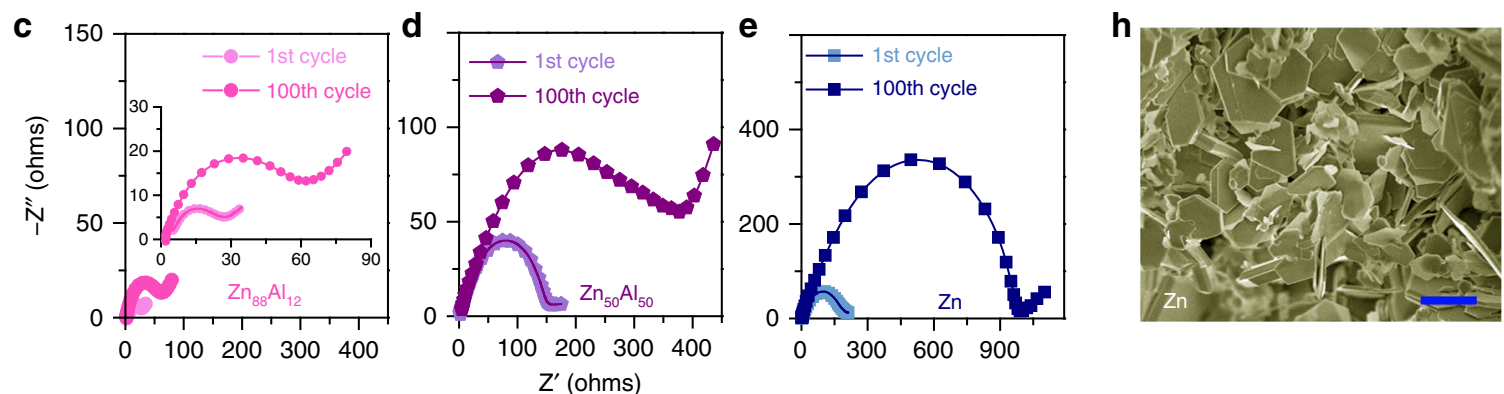

Fig. 4 Electrochemical performance of symmetric batteries of $\mathbf{Z n}$ or $\mathbf{Z n - A l}$ alloy electrodes. a Comparison of voltage profiles for monometallic $\mathrm{Zn}$, hypoeutectic $\mathrm{Zn}_{50} \mathrm{Al}_{50}$ and eutectic $\mathrm{Zn}_{88} \mathrm{Al}_{12}(\lambda=\sim 450 \mathrm{~nm})$ symmetric batteries during $\mathrm{Zn}$ stripping/plating at various current densities from 1 to $5 \mathrm{C}$ in aqueous $\mathrm{ZnSO}_{4}$ electrolyte with the absence of $\mathrm{O}_{2}$, where $1 \mathrm{C}=0.5 \mathrm{~mA} \mathrm{~cm}^{-2}$. $\mathbf{b}$ Long-term $\mathrm{Zn}$ stripping/plating cycling of symmetric batteries of monometallic $\mathrm{Zn}$, hypoeutectic $\mathrm{Zn}_{50} \mathrm{Al}_{50}$ or eutectic $\mathrm{Zn}_{88} \mathrm{Al}_{12}$ alloys $(\lambda=\sim 450 \mathrm{~nm})$ at the current density of $0.5 \mathrm{~mA} \mathrm{~cm}^{-2}$ in aqueous $\mathrm{ZnSO}_{4}$ electrolyte with the absence of $\mathrm{O}_{2}$. c-e Comparisons of EIS spectra for eutectic $\mathrm{Zn}_{88} \mathrm{Al}_{12}\left(\lambda=\sim 450 \mathrm{~nm}\right.$ ) (c), hypoeutectic $\mathrm{Zn}_{50} \mathrm{Al}_{50}$ (d) monometallic $\mathrm{Zn}(\mathbf{e})$ symmetric batteries after the $1^{\text {st }}$ and $100^{\text {th }}$ cycles in aqueous $\mathrm{ZnSO}_{4}$ electrolyte in the absence of $\mathrm{O}_{2}$. Inset: Expanded view for EIS of $Z \mathrm{n}_{88} \mathrm{Al}{ }_{12}$. $\mathbf{f}-\mathbf{h}$ SEM images of eutectic $Z_{88} \mathrm{Al}_{12}(\lambda=\sim 450 \mathrm{~nm})(\mathbf{f})$, hypoeutectic $\mathrm{Zn}_{50} \mathrm{Al} l_{50}(\mathbf{g})$ monometallic $\mathrm{Zn}$ (h), electrodes after long-term $\mathrm{Zn}$ stripping/plating cycling measurements for 2000,520 , and $42 \mathrm{~h}$ in aqueous $\mathrm{ZnSO}_{4}$ electrolyte with the absence of $\mathrm{O}_{2}$, respectively. Scale bare, $5 \mu \mathrm{m}$ (f-h).

to the $\mathrm{Zn} / \mathrm{K}_{x} \mathrm{MnO}_{2}$ battery, the $\mathrm{Zn}_{88} \mathrm{Al}_{12} / \mathrm{K}_{x} \mathrm{MnO}_{2}$ has remarkably enhanced current density and shifts anodic/cathodic peaks to more negative/positive voltages, respectively, indicating that the $\mathrm{Zn}_{88} \mathrm{Al}_{12}$ is more conducive to the $\mathrm{Zn}$ storage/delivery than the $\mathrm{Zn}^{4,7,8,18}$. As a result, the $\mathrm{Zn}_{88} \mathrm{Al}_{12} / \mathrm{K}_{x} \mathrm{MnO}_{2}$ battery exhibits a superior rate capability in the scan rates from 0.3 to $5 \mathrm{mV} \mathrm{s}^{-1}$ (Supplementary Fig. 17a, b). As shown in Fig. 5b, the $\mathrm{Zn}_{88} \mathrm{Al}_{12} /$ $\mathrm{K}_{x} \mathrm{MnO}_{2}$ achieves a specific capacity of as high as $\sim 294 \mathrm{mAh} \mathrm{g}^{-1}$ at $0.3 \mathrm{mV} \mathrm{s}^{-1}$. Even when the scan rate is increased to $5 \mathrm{mV} \mathrm{s}^{-1}$ (i.e., the discharge time of $160 \mathrm{~s}$ ), it still retains the capacity of $\sim 145 \mathrm{mAh} \mathrm{g}^{-1}$, about four-fold higher than the value of the $\mathrm{Zn} /$ $\mathrm{K}_{x} \mathrm{MnO}_{2}$ battery $\left(\sim 36 \mathrm{mAh} \mathrm{g}^{-1}\right)$. The expectation that the lamella-structured eutectic $\mathrm{Zn}_{88} \mathrm{Al}_{12}$ alloy ameliorates the kinetics of $\mathrm{Zn}$ strippling/plating is further verified by the EIS analysis (Fig. $5 \mathrm{c}$ ), with the $R_{\mathrm{CT}}$ value of the $\mathrm{Zn}_{88} \mathrm{Al}_{12} / \mathrm{K}_{x} \mathrm{MnO}_{2}$ being $\sim 66$ $\Omega$ lower than that of the $\mathrm{Zn} / \mathrm{K}_{x} \mathrm{MnO}_{2}$ (inset of Fig. $5 \mathrm{c}$ ). Figure $5 \mathrm{~d}$ presents typical voltage profiles for the charge/discharge processes of $\mathrm{Zn}_{88} \mathrm{Al}_{12} / \mathrm{K}_{x} \mathrm{MnO}_{2}$ and $\mathrm{Zn} / \mathrm{K}_{x} \mathrm{MnO}_{2}$ batteries at a current density of $0.3 \mathrm{~A} \mathrm{~g}^{-1}$, with the plateaus that are consistent with the redox peaks in the CV curves shown in Fig. 5a. Because of the improved $\mathrm{Zn}$ stripping/plating in the eutectic $\mathrm{Zn}_{88} \mathrm{Al}_{12}$ anode, the $\mathrm{Zn}_{88} \mathrm{Al}_{12} / \mathrm{K}_{x} \mathrm{MnO}_{2}$ evidently outperforms the $\mathrm{Zn} / \mathrm{K}_{x} \mathrm{MnO}_{2}$ at various charge/discharge rates (Fig. 5e and Supplementary Fig. 18). As shown in the Ragone plot, the energy densities of $\mathrm{Zn}_{88} \mathrm{Al}_{12} / \mathrm{K}_{x} \mathrm{MnO}_{2}$ battery, based on the mass of $\mathrm{K}_{x} \mathrm{MnO}_{2}$ cathode, reaches $\sim 230 \mathrm{Wh} \mathrm{kg}^{-1}$, more than four-fold higher than the value of $\mathrm{Zn} / \mathrm{K}_{x} \mathrm{MnO}_{2}$ at the electrical power of $\sim 550 \mathrm{~kW}$ $\mathrm{kg}^{-1}$. Based on the total mass of anode and cathode in the full $\mathrm{Zn}_{88} \mathrm{Al}_{12} / \mathrm{K}_{x} \mathrm{MnO}_{2}$ battery, the overall energy density can reach $\sim 142 \mathrm{Wh} \mathrm{kg}^{-1}$ by lowering the anode-to-cathode mass ratio to 3:1 (Supplementary Fig. 19). Supplementary Fig. 20 shows the self-discharge performance of the $\mathrm{Zn}_{88} \mathrm{Al}_{12} / \mathrm{K}_{x} \mathrm{MnO}_{2}$ battery. In the $\mathrm{O}_{2}$-absent electrolyte, the voltage of $\mathrm{Zn}_{88} \mathrm{Al}_{12} / \mathrm{K}_{x} \mathrm{MnO}_{2}$ battery drops to $1.481 \mathrm{~V}$ in $\sim 13 \mathrm{~h}$, slower than the one with the $\mathrm{O}_{2}$-present electrolyte, of which the voltage decreases to $1.472 \mathrm{~V}$ in $\sim 6 \mathrm{~h}$. The evident voltage drop is due to the pseudocapacitive discharge behavior, which is probably boosted by the presence of $\mathrm{O}_{2}$. While in the subsequent $600 \mathrm{~h}$, the $\mathrm{Zn}_{88} \mathrm{Al}_{12} / \mathrm{K}_{x} \mathrm{MnO}_{2}$ batteries with the $\mathrm{O}_{2}$-present and $\mathrm{O}_{2}$-absent electrolytes exhibit a voltage plateau with very low self-discharge $\left(\sim 0.1 \mathrm{mV} \mathrm{h}^{-1}\right)$ because of ultralow insertion kinetics of $\mathrm{Zn}^{2+23-25,43}$. The cycling life of $\mathrm{Zn}_{88} \mathrm{Al}_{12} / \mathrm{K}_{x} \mathrm{MnO}_{2}$ batteries is tested by galvanostatic charge/discharge at current densities of 0.5 and $5 \mathrm{Ag}^{-1}$, respectively (Fig. $5 \mathrm{f}$ and Supplementary Fig. 21). The significant 

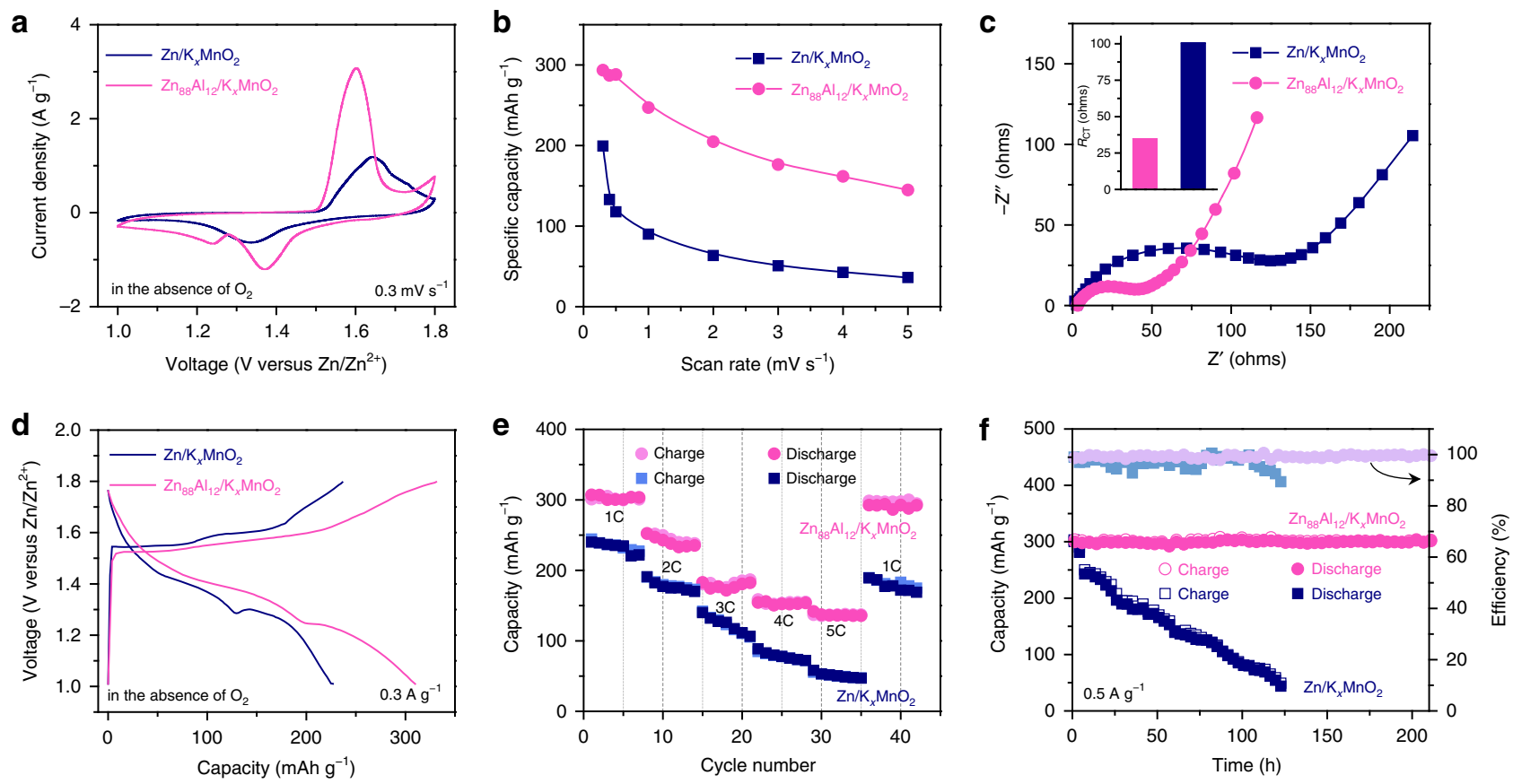

Fig. 5 Electrochemical performance of zinc-ion full batteries. a Typical CV curves for $\mathrm{Zn}_{88} \mathrm{Al}_{12} / \mathrm{K}_{x} \mathrm{MnO}_{2}$ and $\mathrm{Zn} / \mathrm{K}_{x} \mathrm{MnO}_{2}$ batteries, which are constructed with the $\mathrm{K}_{x} \mathrm{MnO}_{2}$ nanofibers as the cathode and the eutectic $\mathrm{Zn}_{88} \mathrm{Al}_{12}$ alloy $(\lambda=\sim 450 \mathrm{~nm})$ or the monometallic $\mathrm{Zn}$ as the anode, in the $\mathrm{O}_{2}$-absent $\mathrm{ZnSO}{ }_{4}$ aqueous electrolyte. Scan rate: $0.3 \mathrm{mV} \mathrm{s}^{-1}$. b Specific capacities for $\mathrm{Zn}_{88} \mathrm{Al}_{12} / \mathrm{K}_{x} \mathrm{MnO}_{2}$ and $\mathrm{Zn} / \mathrm{K}_{x} \mathrm{MnO}_{2}$ batteries at various scan rates. c EIS spectra of $\mathrm{Zn}_{88} \mathrm{Al}_{12} / \mathrm{K}_{x} \mathrm{MnO}_{2}$ and $\mathrm{Zn} / \mathrm{K}_{x} \mathrm{MnO}_{2}$ batteries and their corresponding $R_{\mathrm{CT}}$ values (inset) in the $\mathrm{O}_{2}$-absent $\mathrm{ZnSO}$ aqueous electrolyte. $\mathbf{d}$ Typical voltage profiles of $\mathrm{Zn}_{88} \mathrm{Al}_{12} / \mathrm{K}_{x} \mathrm{MnO}_{2}$ and $\mathrm{Zn} / \mathrm{K}_{x} \mathrm{MnO}_{2}$ batteries at the charge/discharge current density of $0.3 \mathrm{Ag}^{-1}$. e Comparison for rate capabilities of $\mathrm{Zn}_{88} \mathrm{Al}_{12} / \mathrm{K}_{x} \mathrm{MnO}_{2}$ and $\mathrm{Zn} / \mathrm{K}_{x} \mathrm{MnO}_{2}$ batteries at various rates from 1 to $5 \mathrm{C}$. $\mathbf{f}$ Capacity retention and coulombic efficiency of the $\mathrm{Zn}_{88} \mathrm{Al}_{12} / \mathrm{K}_{x} \mathrm{MnO}_{2}$ battery in a long-term cycling test at $0.5 \mathrm{Ag}^{-1}$, comparing with those of the $\mathrm{Zn} / \mathrm{K}_{x} \mathrm{MnO}_{2}$ battery.

capacitance retention, about $100 \%$ of the initial capacitance after more than $200 \mathrm{~h}$ or 5000 cycles, indicates its impressive long-term durability with nearly $100 \%$ efficiency in the voltage window between 1.0 and $1.8 \mathrm{~V}$. In sharp contrast, the $\mathrm{Zn} / \mathrm{K}_{x} \mathrm{MnO}_{2}$ battery undergoes fast capacity degradation (Fig. 5f). This probably results from the irreversibility issues of monometallic $\mathrm{Zn}$, i.e., the dendrite formation and growth associated with side reactions, in view that the $\mathrm{K}_{x} \mathrm{MnO}_{2}$ cathode still maintains the initial morphology and crystallographic structure after the cycling measurement (Supplementary Fig. 22).

\section{Discussion}

In summary, we have proposed eutectic-composition alloying, based on the $\mathrm{Zn}_{88} \mathrm{Al}_{12}$ alloy with a lamellar structure composed of alternating $\mathrm{Zn}$ and $\mathrm{Al}$ nanolamellas, as an effective strategy to tackle irreversibility issues of $\mathrm{Zn}$ metal anode caused by the growth of dendrites and cracks during the stripping/plating processes. By virtue of symbiotic less-noble Al lamellas, which not only protects the constituent $\mathrm{Zn}$ lamellas from the formation of irreversible $\mathrm{ZnO}$ or $\mathrm{Zn}(\mathrm{OH})_{2}$ by-product but also in-situ form stable $\mathrm{Al} / \mathrm{Al}_{2} \mathrm{O}_{3}$ interlamellar patterns during the $\mathrm{Zn}$ stripping and in turn guide subsequent growth of $\mathrm{Zn}$, the eutectic $\mathrm{Zn}_{88} \mathrm{Al}_{12}$ (at\%) alloys exhibit superior dendrite-free $\mathrm{Zn}$ stripping/plating behaviors, with low overpotential and high coulombic efficiency, for more than $2000 \mathrm{~h}$ in $\mathrm{O}_{2}$-absent aqueous $\mathrm{ZnSO}_{4}$ electrolyte. The use of the eutectic $\mathrm{Zn}_{88} \mathrm{Al}_{12}$ alloy as the anode enlists the $\mathrm{Zn}$ ion full batteries with the $\mathrm{K}_{x} \mathrm{MnO}_{2}$ cathode to deliver energy density of $\sim 230 \mathrm{Wh} \mathrm{kg}^{-1}$ (based on the mass of $\mathrm{K}_{x} \mathrm{MnO}_{2}$ cathode) at high levels of electrical power and retain $\sim 100 \%$ capacity after a long-term charge/discharge cycling measurement, remarkably outperforming the battery based on monometallic $\mathrm{Zn}$ anode. By adjusting the anode-to-cathode mass ratio to $3: 1$, the overall energy density of Zn-Mn AR-ZIB can reach $\sim 142 \mathrm{Wh}$ $\mathrm{kg}^{-1}$ based on total mass of anode and cathode. The strategy of eutectic-composition alloying can also be extended to other metal anodes for the development of next-generation secondary batteries.

\section{Methods}

Preparation of $\mathbf{Z n - A l}$ alloys and $\mathbf{K}_{\mathbf{x}} \mathbf{M n O}_{\mathbf{2}}$ nanofibers. The $\mathrm{Zn}_{x} \mathrm{Al}_{100-x}(x=50$, $88,100$ at $\%)$ alloys made of high-purity $\mathrm{Zn}(99.994 \%)$ and $\mathrm{Al}(99.996 \%)$ were prepared by induction melting in high-purity alumina crucibles within $\mathrm{Ar}$ air. These alloy ingots were produced through pouring casting, of which the cooling rates were controlled by making use of different casting moulds, i.e., the heated iron moulds $\left(\sim 10 \mathrm{~K} \mathrm{~s}^{-1}\right)$ and the copper moulds with air- $\left(\sim 30 \mathrm{~K} \mathrm{~s}^{-1}\right)$ and watercooling $\left(\sim 300 \mathrm{~K} \mathrm{~s}^{-1}\right)$ methods. The as-cast $\mathrm{Zn}_{x} \mathrm{Al}_{100-x}$ ingots were cut into alloy sheets with thickness of $\sim 400 \mu \mathrm{m}$ along the perpendicular direction of lamellar structure and further polished for the use as the anodic electrodes. The synthesis of $\mathrm{K}_{0.12} \mathrm{MnO}_{2}$ nanobelts was carried out by a modified hydrothermal method. Typically, the Teflon-lined steel autoclave filled with the mixture of $40-\mathrm{mM} \mathrm{KMnO}_{4}$ and 40- $\mathrm{mM} \mathrm{NH}_{4} \mathrm{Cl}$ was heated at $150^{\circ} \mathrm{C}$ for $24 \mathrm{~h}$ in an oil bath and magnetically stirred at a speed of $250 \mathrm{rpm}$. The as-synthesized $\mathrm{K}_{0.12} \mathrm{MnO}_{2}$ nanomaterials were collected and washed with ultrapure water for five times using a centrifuge to remove residues.

Structural and chemical characterizations. The metallographic microstructure of $\mathrm{Zn}_{x} \mathrm{Al}_{100-x}$ alloy sheets was investigated by using a confocal laser scanning microscope (OLS3000, Olympus) after conventional grinding and mechanical polishing, followed by chemical etching in acetic picric solution $(5 \mathrm{ml} \mathrm{HNO}$ and 5 $\mathrm{ml} \mathrm{HF}, 90 \mathrm{ml}$ ultrapure water). The electron micrographic structures were characterized by using a field-emission scanning electron microscope (JEOL, JSM$6700 \mathrm{~F}, 15 \mathrm{kV}$ ) equipped with an X-ray energy-dispersive microscopy, and a fieldemission transmission electron microscope (JEOL, JEM-2100F, $200 \mathrm{kV}$ ). XRD measurements were conducted on a D/max2500pc diffractometer using $\mathrm{Cu} \mathrm{Ka}$ radiation. Ion concentrations in electrolytes were analyzed by inductively coupled plasma optical emission spectrometer (ICP-OES, Thermo electron). XPS analysis was conducted on a Thermo ECSALAB 250 with an $\mathrm{Al}$ anode. Charging effects were compensated by shifting binding energies based on the adventitious $C 1$ s peak $(284.8 \mathrm{eV})$. 
Electrochemical measurements. Symmetrical cells were assembled with two identical $\mathrm{Zn}_{x} \mathrm{Al}_{100-x}$ alloy or pure $\mathrm{Zn}$ sheets $(0.5 \mathrm{~cm} \times 0.5 \mathrm{~cm} \times 40 \mu \mathrm{m})$, which were separated by glass fiber membrane (GFM) in $2 \mathrm{M} \mathrm{ZnSO}_{4}$ aqueous solution with/ without $\mathrm{N}_{2}$ purgation. Electrochemical stripping/plating behaviors of $\mathrm{Zn} / \mathrm{Zn}^{2+}$ were measured by galvanostatic charge and discharge at various current densities from 1 to $5 \mathrm{~mA} \mathrm{~cm}^{-2}$. The cycling durability tests were performed at the current density of $0.5 \mathrm{~mA} \mathrm{~cm}{ }^{-2}$. To prove its feasibility of the lamella-structured eutectic $\mathrm{Zn}_{88} \mathrm{Al}_{12}$ alloy anodes in practical aqueous rechargeable $\mathrm{Zn}$-ion batteries, full cells were further assembled with the $\mathrm{Zn}_{88} \mathrm{Al}_{12}$ alloy sheet as the anode, the $\mathrm{K}_{0.12} \mathrm{MnO}_{2}$ as the cathode, the GFM as the separator, with the $2 \mathrm{M} \mathrm{ZnSO}_{4}$ aqueous solution containing $0.2 \mathrm{M} \mathrm{MnSO}_{4}$ as the aqueous electrolyte. Therein, the $\mathrm{K}_{0.12} \mathrm{MnO}_{2}$ electrodes were prepared by homogeneously mixing $\mathrm{K}_{0.12} \mathrm{MnO}_{2}$ nanobelts, super-P acetylene black conducting agent and poly(vinylidene difluoride) binder with a weight ratio of 70:20:10 in N-methyl-2-pyrrolidone (NMP), and then pasting on stainless steel foil with the loading mass of $1.0 \mathrm{mg} \mathrm{cm}^{-2}$. Cyclic voltammetry was conducted on an electrochemical analyzer (Ivium Technology) in the voltage range of 1 and $1.8 \mathrm{~V}$ at scan rates from 0.3 to $5 \mathrm{mV} \mathrm{s}^{-1}$. Electrochemical impedance spectroscopy (EIS) measurements were performed in sealed cells with $\mathrm{O}_{2}$ - or $\mathrm{N}_{2}$-saturated aqueous $2 \mathrm{M}$ $\mathrm{ZnSO}_{4}$ electrolytes over the frequency ranging from $100 \mathrm{kHz}$ to $10 \mathrm{mHz}$ with an amplitude of $10 \mathrm{mV}$ at room temperature. The rate capability and cycling performance were carried out on a battery test system. Self-discharge measurements were carried out by charging $\mathrm{Zn}_{88} \mathrm{Al}_{12} / \mathrm{K}_{x} \mathrm{MnO}_{2}$ to $1.8 \mathrm{~V}$, followed by open-circuit potential self-discharging for $600 \mathrm{~h}$. The coulombic efficiency (CE) of $\mathrm{Zn}$ plating/ stripping was evaluated by chronocoulometry method, in which the eutectic $\mathrm{Zn}_{88} \mathrm{Al}_{12}$ alloy or pure $\mathrm{Zn}$ electrode were used as the working electrode and the $\mathrm{Zn}$ foils as the counter and reference electrodes in the three-electrode cell in the $\mathrm{O}_{2-}$ absent $2 \mathrm{M} \mathrm{ZnSO}_{4}$ electrolyte. The chronocoulometry measurements were conducted at the potential of -0.2 and $0.2 \mathrm{~V}$ (versus $\mathrm{Zn} / \mathrm{Zn}^{2+}$ ) for $600 \mathrm{~s}$, respectively to plate and stripe $\mathrm{Zn}$. The $\mathrm{CE}$ was calculated by the stripping/plating capacities.

\section{Data availability}

All relevant data are available from the corresponding authors upon request.

Received: 30 September 2019; Accepted: 13 March 2020;

Published online: 02 April 2020

\section{References}

1. Dunn, B., Kamath, H. \& Tarascon, J. M. Electrical energy storage for the grid: a battery of choices. Science 334, 928-935 (2011)

2. Yang, Z. et al. Electrochemical energy storage for green grid. Chem. Rev. 111, 3577-3613 (2011).

3. Kim, H. et al. Metallic anodes for next-generation secondary batteries. Chem. Soc. Rev. 42, 9011-9034 (2013).

4. Ming, J., Guo, J., Xia, C., Wang, W. \& Alshareef, H. N. Zinc-ion batteries: materials, mechanisms, and applications. Mater. Sci. Eng. R. 135, 58-84 (2019).

5. Parker, J. F. et al. Rechargeable nickel-3D zinc batteries: an energy-dense, safer alternative to lithium-ion. Science 356, 415-418 (2017).

6. Hu, E. \& Yang, X. Q. Rejuvenating zinc batteries. Nat. Mater. 17, 480-481 (2018).

7. Song, M., Tan, H., Chao, D. \& Fan, H. J. Recent advances in Zn-ion batteries. Adv. Funct. Mater. 28, 1802564 (2018).

8. Fang, G., Zhou, J., Pan, A. \& Liang, S. Recent advances in aqueous zinc-ion batteries. ACS Energy Lett. 3, 2480-2501 (2018).

9. Shoji, T., Hishinuma, M. \& Yamamoto, T. Zinc-manganese dioxide galvanic cell using zinc sulphate as electrolyte. Rechargeability of the cell. J. Appl. Electrochem. 18, 521-526 (1988).

10. Xu, C., Li, B., Du, H. \& Kang, F. Energetic zinc ion chemistry: the rechargeable zinc ion battery. Angew. Chem. Int. Ed. 51, 933-935 (2012).

11. Pan, $\mathrm{H}$. et al. Reversible aqueous zinc/manganese oxide energy storage from conversion reaction. Nat. Energy 1, 16039 (2016).

12. Zhang, N. et al. Rechargeable aqueous zinc-manganese dioxide batteries with high energy and power densities. Nat. Commun. 8, 405 (2017).

13. Huang, J. et al. Polyaniline-intercalated manganese dioxide nanolayers as a high-performance cathode material for an aqueous zinc-ion battery. Nat. Commun. 9, 2906 (2018).

14. Kundu, D., Adams, B. D., Duffort, V., Vajargah, S. H. \& Nazar, L. F. A highcapacity and long-life aqueous rechargeable zinc battery using a metal oxide intercalation cathode. Nat. Energy 1, 16119 (2016).

15. Yan, $\mathrm{M}$. et al. Water-lubricated intercalation in $\mathrm{V}_{2} \mathrm{O}_{5} \cdot \mathrm{nH}_{2} \mathrm{O}$ for high-capacity and high-rate aqueous rechargeable zinc batteries. Adv. Mater. 30, 1703725 (2018).

16. Xia, C., Guo, J., Li, P., Zhang, X. \& Alshareef, H. N. Highly stable aqueous zinc-ion storage using a layered calcium vanadium oxide bronze cathode. Angew. Chem. Int. Ed. 57, 3943-3948 (2018).
17. Yang, $\mathrm{Y}$. et al. $\mathrm{Li}^{+}$intercalated $\mathrm{V}_{2} \mathrm{O}_{5} \cdot \mathrm{nH}_{2} \mathrm{O}$ with enlarged layer spacing and fast ion diffusion as an aqueous zinc-ion battery cathode. Energy Environ. Sci. 11, 3157-3162 (2018).

18. Chao, D. et al. A high-rate and stable quasi-solid-state zinc-ion battery with novel 2D layered zinc orthovanadate array. Adv. Mater. 30, 1803181 (2018).

19. Kundu, D. et al. Aqueous vs. nonaqueous $\mathrm{Zn}$-ion batteries: consequences of the desolvation penalty at the interface. Energy Environ. Sci. 11, 811-892 (2018).

20. Zhang, L., Chen, L., Zhou, X. \& Liu, Z. Towards high-voltage aqueous metalion batteries beyond $1.5 \mathrm{~V}$ : The zinc/zinc hexacyanoferrate system. Adv. Energy Mater. 5, 1400930 (2015).

21. Xia, C. et al. Rechargeable aqueous zinc-ion battery based on porous framework zinc pyrovanadate intercalation cathode. Adv. Mater. 30, 1705580 (2018).

22. Zhao, Q. et al. High-capacity aqueous zinc batteries using sustainable quinone electrodes. Sci. Adv. 4, eaaol761 (2018).

23. Sun, W. et al. $\mathrm{Zn} / \mathrm{MnO}_{2}$ battery chemistry with $\mathrm{H}^{+}$and $\mathrm{Zn}^{2+}$ coinsertion. $J$. Am. Chem. Soc. 139, 9775-9778 (2017)

24. Wang, F. et al. Reversible oxygen redox chemistry in aqueous zinc-ion batteries. Angew. Chem. Int. Ed. 58, 7062-7067 (2019).

25. Li, H., McRae, L., Firby, C. J. \& Elezzabi, A. Y. Rechargeable aqueous electrochromic batteries utilizing Ti-substituted tungsten molybdenum oxide based $\mathrm{Zn}^{2+}$ ion intercalation cathodes. Adv. Mater. 31, 1807065 (2019).

26. Parker, J. F., Chervin, C. N., Nelson, E. S., Rolison, D. R. \& Long, J. W. Wiring zinc in three-dimension re-writes battery performance-dendrite-free cycling. Energy Environ. Sci. 7, 1117-1124 (2014).

27. Yufit, V. et al. Operando visualization and multi-scale tomography studies of dendrite formation and dissolution in zinc batteries. Joule 3, 1-18 (2019).

28. Higashi, S., Lee, S. W., Lee, J. S., Takechi, K. \& Cui, Y. Avoiding short circuits from zinc metal dendrites in anode by backside-plating configuration. Nat. Commun. 7, 11801 (2016)

29. Zeng, X., Hao, J., Wang, Z., Mao, J. \& Guo, Z. Recent progress and perspectives on aqueous $\mathrm{Zn}$-based rechargeable batteries with mild aqueous electrolytes. Energy Storage Mater. 20, 410-437 (2019).

30. Wang, F. et al. Highly reversible zinc metal anode for aqueous batteries. Nat. Mater. 17, 543-549.

31. Yang, H., Cao, Y., Ai, X. \& Xiao, L. Improved discharge capacity and suppressed surface passivation of zinc anode in dilute alkaline solution using surfactant additives. J. Power Sources 128, 97-101 (2004).

32. Xiong, W. et al. Controlling the sustainability and shape change of the zinc anode in rechargeable aqueous $\mathrm{Zn} / \mathrm{LiMn}_{2} \mathrm{O}_{4}$ battery. Energy Storage Mater. 15, 131-138 (2018)

33. Diggle, J. W., Despic, A. R. \& Bockris, J. O. 'M. The Mechanism of the dendritic electrocrystallization of zinc. J. Electrochem. Soc. 116, 1503-1514 (1969).

34. Monroe, C. \& Newman, J. Dendrite growth in lithium/polymer systems: a propagation model for liquid electrolytes under galvanostatic conditions. J. Electrochem. Soc. 150, A1377-A1384 (2003).

35. Elia, G. A. et al. An overview and future perspectives of aluminum batteries. Adv. Mater. 28, 7564-7579 (2016)

36. Sun, L., Chien, C. L. \& Searson, P. C. Fabrication of nanoporous nickel by electrochemical dealloying. Chem. Mater. 16, 3125-3129 (2004).

37. Ding, F. et al. Dendrite-free lithium deposition via self-healing electrostatic shield mechanism. J. Am. Chem. Soc. 135, 4450-4456 (2013).

38. Salgado-Ordorica, M. A. \& Rappaz, M. Twinned dendrite growth in binary aluminum alloys. Acta Mater. 56, 5708-5718 (2008).

39. Cahn, R.W. \& Haasen, P. Physical Metallurgy. (Netherlands, 1996).

40. Jackson, K. A. \& Hunt, J. D. Lamellar and rod eutectic growth. Metal. Soc. AIME 236, 1129-1141 (1966).

41. $\mathrm{Xu}, \mathrm{W}$. et al. Lithium metal anodes for rechargeable batteries. Energy Environ. Sci. 7, 513-537 (2014).

42. Liang, Z. et al. Composite lithium metal anode by melt infusion of lithium into a 3D conducting scaffold with lithiophilic coating. Proc. Natl Acad. Sci. USA 113, 2862-2867 (2016).

43. Wan, F. et al. Aqueous rechargeable zinc/sodium vanadate batteries with enhanced performance from simultaneous insertion of dual carrier. Nat. Commun. 9, 1656 (2018).

44. Tang, $\mathrm{X}$. et al. Mechanical force-driven growth of elongated bending $\mathrm{TiO}_{2}$ based nanotubular materials for ultrafast rechargeable lithium ion batteries. Adv. Mater. 26, 6111-6118 (2014).

\section{Acknowledgements}

This work was supported by National Natural Science Foundation of China (No 51871107, 51631004), Top-notch Young Talent Program of China (W02070051), Chang Jiang Scholar Program of China (Q2016064), the Program for JLU Science and Technology Innovative Research Team (JLUSTIRT, 2017TD-09), the Fundamental Research Funds for the Central Universities, and the Program for Innovative Research Team (in Science and Technology) in University of Jilin Province. 


\section{Author contributions}

X.Y.L. and Q.J. conceived and designed the experiments. S.B.W., Q.R., R.Q.Y., H.S., Z.W. and M.Z. carried out the fabrication of materials and performed the electrochemical measurements and microstructural characterizations. X.Y.L. and Q.J. wrote the paper, and all authors discussed the results and commented on the manuscript.

\section{Competing Interests}

The authors declare no competing interests.

\section{Additional information}

Supplementary information is available for this paper at https://doi.org/10.1038/s41467020-15478-4

Correspondence and requests for materials should be addressed to X.-Y.L. or Q.J.

Peer review information Nature Communications thanks Fei Wang and the other, anonymous, reviewer(s) for their contribution to the peer review of this work. Peer reviewer reports are available.
Reprints and permission information is available at http://www.nature.com/reprints

Publisher's note Springer Nature remains neutral with regard to jurisdictional claims in published maps and institutional affiliations.

(c) Open Access This article is licensed under a Creative Commons Attribution 4.0 International License, which permits use, sharing, adaptation, distribution and reproduction in any medium or format, as long as you give appropriate credit to the original author(s) and the source, provide a link to the Creative Commons license, and indicate if changes were made. The images or other third party material in this article are included in the article's Creative Commons license, unless indicated otherwise in a credit line to the material. If material is not included in the article's Creative Commons license and your intended use is not permitted by statutory regulation or exceeds the permitted use, you will need to obtain permission directly from the copyright holder. To view a copy of this license, visit http://creativecommons.org/ licenses/by/4.0/.

(C) The Author(s) 2020 